\title{
Role of Photodynamic Therapy in the Management of Gastrointestinal Cancer
}

\author{
A.K. Kubba \\ University of Manchester, UK
}

\section{Key Words}

Photodynamic therapy - Cancer, gastrointestinal tract • Management of malignancies

\begin{abstract}
Background: Surgery for cancer of the gastrointestinal tract is associated with high morbidity and mortality, especially in older patients. A significant proportion of patients cannot be cured and would be referred for palliative therapy. Others may have early cancer but are deemed unfit for surgery. Chemotherapy and external radiotherapy are suitable for only a proportion of patients. Therefore, photodynamic therapy may have a role in the management of these patients. It was the possibility of achieving selective tumour necrosis with sparing of normal tissue that made this treatment extremely appealing compared to other conventional tumour therapy. Method: The literature is reviewed (after an extensive Medline search 1975-1997) regarding the scientific basis of photodynamic therapy and the clinical experience to date with this therapy in the management of malignancies of the gastrointestinal tract. Results and Conclusions: Photodynamic therapy holds the promise of an eradication form of treatment for early cancer especially for patients deemed unfit for other treatment. It may also prove a useful supplement to other techniques in order to eliminate small residual areas of tumour left after the
\end{abstract}

\begin{tabular}{ll}
\hline KARGER & (1) 1999 S. Karger AG, Basel \\
0012-2823/99/0601-0001\$17.50/0 \\
Fax + 4161306 12 34 & Accessible online at: \\
$\begin{array}{l}\text { E-Mail karger@karger.ch } \\
\text { www.karger.com }\end{array}$ & http://BioMedNet.com/karger
\end{tabular}

main bulk has been removed by other methods. The use of photodynamic therapy in the palliative management of gastrointestinal tract cancer is likely to be limited.

\section{Introduction}

Photodynamic therapy (PDT) involves the interaction of light administered after the introduction of a photosensitising agent (dye).

In 1913 Meyer-Betz [1] injected himself with $200 \mathrm{mg}$ haematoporphyrin (HPD) and within minutes of light exposure he developed severe pain and swelling confined to light-exposed areas.

In 1966, Lipson et al. [2] reported the use of HPD to treat cancer in patients with recurrent breast carcinoma with some evidence of response. In the 1990s there has been an increasing interest in PDT because of the development of more powerful sensitisers, more advanced light-delivery systems [3] and because of its increasing use in Barrett's oesophagus.

There are four fundamental variables in the action of PDT, they are the target tissue, the oxygen intermediaries, the light source and the photosensitising agent. Earlier researchers hoped and sometimes found photosensitisers to have a greater affinity towards and accumulate in premalignant and malignant cells causing selective cell death.
Mr. A.K. Kubba
c/o 32 Falkland St (1/R)
Glasgow G12 9QY (UK)
Tel. +44 1912227157, Fax +44 1912228514 
Table 1. List of photosensitisers used

\begin{tabular}{|c|c|c|}
\hline Photosensitiser & $\begin{array}{l}\text { Peak wavelength } \\
\text { nm }\end{array}$ & Comments \\
\hline 5-Aminolaevulinic acid (5ALA) & 632 & $\begin{array}{l}\text { Limited tissue penetration, can be taken orally, } \\
\text { low skin photosensitivity }\end{array}$ \\
\hline HpD/Photofrin & 630 & $\begin{array}{l}\text { Instability at room temperature, long skin } \\
\text { photosensitivity }\end{array}$ \\
\hline Profimer sodium & 630 & Long skin photosensitivity ( $>6$ weeks) \\
\hline Phthalocyanines $(\mathrm{Pc})$ & $675-700$ & Second-generation photosensitisers \\
\hline Zn II Phthalocyanine & $675-700$ & Strong light absorption and deep tissue penetration \\
\hline Aluminium sulphonated Pc (AISPc) & 675 & $\begin{array}{l}\text { High tumour selectivity and cytotoxicity, water } \\
\text { insoluble }\end{array}$ \\
\hline Benzoporphyrin derivatives & 690 & Low skin photosensitivity \\
\hline Mesotetrahydroxyphenylchlorin (mTHPC) & 652 & $\begin{array}{l}\text { High selectivity for tumour cells ( } 1: 14 \text { ?), } \\
\text { suitable for irradiation with diode laser }\end{array}$ \\
\hline Mono- $L$-aspartyle chlorin e6(NPe6) & 664 & $\begin{array}{l}\text { Low skin photosensitivity, limited clinical } \\
\text { experience }\end{array}$ \\
\hline Indocyanine green & $790-805$ & $\begin{array}{l}\text { No clinical experience reported (mostly used in cell } \\
\text { cultures), little or no skin photosensitivity }\end{array}$ \\
\hline
\end{tabular}

The light wavelength and method of administration must be appropriate to initiate a photochemical reaction (table 1) [4-28].

Cell death is mediated by reactive intermediaries (such as singlet oxygen) [29] which are produced during photooxidation reactions within these cells [30] and at cell membrane sites [31]. Tumour affinity to the sensitiser may be influenced by manipulation of other co-factors such as $\mathrm{pH}[32]$.

In the 1970s Dougherty et al. [33] reported encouraging results in the control of local and regional recurrences of breast cancer using PDT (HPD as a photosensitiser). They also reported a high therapeutic ratio due to their observation of a higher uptake of HPD into malignant tissue compared to normal tissue. Further studies by the same group reported successes in the treatment of cancers of the colon, skin, endometrium and the prostate [34], which sparked off an increasing interest in PDT.

Apart from its use in the treatment of gastrointestinal tumours, PDT has been used in the treatment of malignancies in the brain [35], skin [36], ovaries [37], uterus [38], lungs [39], and oral cavity [40] for more than a decade. More recently, there has been considerable interest in the use of this therapy in the management of Barrett's oesophagus [41-43] and intimal hyperplasia of peripheral arteries [44].
The aim of this review is to summarise the scientific basis of PDT and also to review the experimental and clinical experience to date relevant to cancer of the oesophagus, stomach and colon.

\section{Mechanism of Action}

\section{Direct Cell Death}

PDT increases the nuclear to cytoplasmic ratio and causes cytomegaly, both of which are thought to be intermediate processes leading to cell death [45-47].

As photofrin is absorbed into the cells, it is diffusely distributed through the cytoplasm and becomes bound primarily to mitochondrial membranes which initiate the cell changes induced by light exposure and are catalysed by membrane-bound enzymes such as cytochrome $\mathrm{C}$ oxidase and succinate dehydrogenase [48].

Cell death results from the production of oxygen free radicals in higher concentrations in tissues containing the photosensitiser, giving rise to a differential effect [49]. The role of reactive oxygen species has been further confirmed in in vitro cultures by incubating these cultures with different concentrations of sodium azide (reactive oxygen species scavenger) resulting in significant inhibition of cell death $[28,45]$. 
Fig. 1. Balloon diffuser.

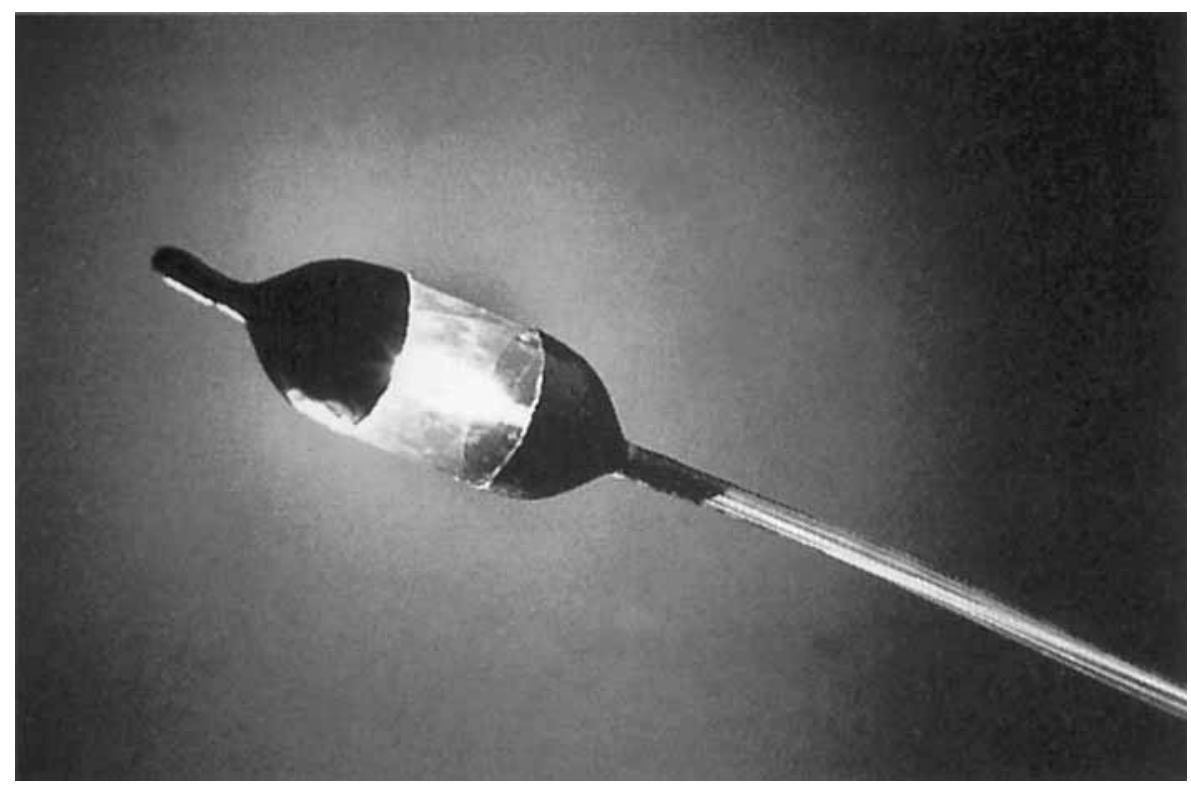

\section{Vascular-Mediated Response}

PDT induces ischaemia in cell cultures $[50,51]$ and treated tissues. This is possibly mediated by prostaglandin $E_{2}$ [52] or high tissue thromboxane release [53], both of which have been found in elevated levels in cells undergoing PDT. In animal experiments, PDT markedly decreases vascular perfusion in tumours and increases tissue hypoxia [54].

Secondary tumour cell death is induced by vascular shutdown [55].

Overholt et al. [56] observed in a canine oesophagus model that the delivery of PDT via a large balloon (2-3.5 $\mathrm{cm}$ in diameter) results in reduced tissue injury. They concluded that excessive pressure on the oesophageal wall reduces the therapeutic effect.

\section{Immunological Response}

Photodynamic therapy is associated with increased production of tumour necrosis factor, interleukin-1B and interleukin 2, which suggests that it may elicit a local macrophage response [57, 58].

The combination of photosensitisers with low-density lipoproteins has been shown to enhance delivery to tumours in mice $[59,60]$. Tumour-associated macrophages are largely responsible for the higher concentration of photosensitisers in tumour cells because of phagocytosis of aggregates or by scavenging of modified lipoproteins $[61,62]$.

Photodynamic Therapy in the Management of Gastrointestinal Cancer

\section{Light Source}

Laser produces a high-intensity energy of a defined wavelength which can be directed to a specific area, and making the laser the most suitable light source for PDT. Optical fibre modifications such as a microlens, a radially diffusing tip or a balloon-diffuser system can be used to adapt the light irradiation to the shape of the target tissue. The balloon-diffuser (fig. 1) system has been shown to be successful in centering the rays of radiation and providing a uniform circumferential and predictable light delivery which minimises the 'hill and valley' effect due to organ folds (especially oesophageal folds) [63-65]. The possibility of contact laser techniques may allow more exact targeting of radiation. The continuous wave dye laser (optically pumped by a krypton or argon ion) and the pulsed dye laser (optically pumped by N2, excimer, or Nd-YAG laser) are both used [66]. A recent study tested the use of a 'Versa-Light' using a xenon lamp in order to find a cheaper alternative to laser therapy [67]. This was tested in animals and used in the treatment of an inoperable rectal cancer in 1 patient. It was thought to be a safe, cheap and effective light source. However, an endoscopic mode of delivery is yet to become available. This light source might be popular because many centres do not have dye laser, the laser equipments are heavy to transport between hospitals and they require complicated electric and cooling installations. This light source has a spectral emission in the 600- to 720-nm region, matching closely the absorption spectra of

Digestion 1999;60:1-10 
existing photosensitisers. Therefore, further work is required to establish the efficacy of this light source and to develop the technology for endoscopic delivery.

New advances in diode laser technology promise considerable simplification for PDT light delivery. These systems could be compact, easily transportable, require only $108 \mathrm{~V}$ power and are considerably less expensive than current PDT laser systems [68]. However, the diode laser available to date has a limited wavelength spectrum, therefore, limiting the type of photosensitiser which can be successfully employed.

\section{Tissue Effects and Side Effects of PDT}

Although the principle behind photodynamic therapy may be different from that used in thermal or laser treatment, the overall tissue effects observed at the site of treatment are rather similar [16]. In the first $72 \mathrm{~h}$ after PDT oedema develops [69]. When the necrotic tissue finally sloughs, perforation remains a risk.

Adverse effects such as nausea, epigastric pain, anorexia, chest discomfort, atrial fibrillation, heart failure, transient elevation of white cell count and temperature, pleural effusion, pulmonary oedema and aspiration pneumonia are all rare, but have been reported after PDT [7073].

When treating superficial oesophageal malignant strictures, post-treatment oesophageal strictures have been reported in a significant minority of patients especially with the use of the older photosensitisers such as HPD (though some of these symptoms might have been secondary to the original pathology rather than the treatment employed).

The reported rate of post-treatment strictures is variable and depends on the tissue involved, the light intensity and the photosensitiser used.

Overholt and Panjehpour [74] reported the treatment of 36 patients with superficial oesophageal cancer and Barrett's oesophagus. Although this group reported an excellent response rate, the rate of stricture formation was $58 \%$. This may be due to the use of sodium porfimer (a strong photosensitiser) in the treatment of superficial lesions. Such a high stricture formation rate is becoming increasingly unacceptable.

Skin photosensitivity is commonly reported in most studies using most photosensitisers. Recently, it has been claimed that skin photosensitivity is significantly reduced when using 5-aminolaevulinic acid (5ALA) [75]. Recently Verspaget et al. [76] reported that in cell cultures PDT causes an intrinsic immunosuppressive effect manifesting in a reduction in natural killer cell activity. No assessment of a possible immunological reaction to PDT in man has been reported.

Further selectivity of the photosensitiser to tumour cells, possibly by combining them with other factors such as serum albumin labelled with tumour-specific monoclonal antibodies or lipoproteins [77] or by injecting them directly into the tumour itself, would allow greater tumour destruction and minimise complications such as skin photosensitivity [78].

Amano et al. [78] examined the hypothesis that intratumour (IT) injection of photosensitiser may carry the advantages of decreasing skin photosensitivity and increasing the tumour concentration of the photosensitiser (thereby increasing tumour destruction). This work was carried out in an animal model of bladder tumour using HPD. It was found that for up to $96 \mathrm{~h}$ after IT versus intraperitoneal injections, the porphyrin levels in the tumour were 3-15 times greater with IT injections. The concentrations in skin and other tissues (muscle, liver, kidney, spleen, bladder and blood) were 1.3-10 times lower after IT injection.

Veenhuizen et al. [79] conducted a similar study and found that local administration of HPD resulted in tissue damage in a dose-dependent manner. Maximal effect was achieved at 6-24 $\mathrm{h}$ after injection with no systemic absorption.

Veenhuizen et al. [79] compared intravenous with intraperitoneal delivery of the photosensitiser photofrin in an animal model of colon cancer. They found no difference in tumour uptake or efficacy but found that a combination of PDT and the hypoxic toxin mitomycin $\mathrm{C}$ proved superior to PDT alone in tumour destruction.

More recently WongKeeSong et al. [80] presented the case of a patient with oesophageal cancer treated by PDT (using intra-lesional injection of porfimer sodium) with satisfactory outcome.

These are interesting studies but the extrapolation of these findings into greater tumour destruction and lesser skin photosensitivity in man is yet to be established. Finally it must be acknowledged that IT injection of the photosensitiser can only be applied to easily accessible single lesion tumours.

Rabeiz et al. [81, 82] advanced the idea that tetrapyrrole modulators such as 1,10-phenanthroline if added to 5ALA can result in greater accumulation of protoporphyrin IX and subsequent cell lysis (on exposure to light) in vitro and in vivo (animal model of solid tumour; BALB/c mice; $p<0.05$ ) compared to using 5ALA alone. 
More recently an encouraging report of the successful use of another pro-drug, the ALA pentyl ester, which was shown to increase the uptake of 5ALA and its greater conversion into PpIX, has been reported [83].

If as anticipated, biological modulators act synergistically with 5ALA resulting in an increased concentration of synthesised photosensitiser and hence leading to a greater tumour destruction upon exposure to light, the search must continue for a safe, non-toxic modulator to enhance sensitiser-mediated PDT. Numerous possible modulators are available which may be used safely in man. This issue we believe merits further investigations.

\section{PDT in the Treatment of Oesophageal Cancer}

Malignant stenosis of the oesophagus is common and unfortunately curative treatment is possible in only a small percentage of patients. The 5 -year survival remains poor [84]. Therefore, many patients who cannot be cured should be referred for palliative therapy. Operative treatment is associated with high morbidity and mortality [85]. Chemotherapy and external radiotherapy are associated with complications and only a proportion of patients respond to these techniques [86]. Therefore, photodynamic therapy may have a role in the management of both early cancers and inoperable malignant oesophageal strictures [87-92].

\section{Early Cancer}

Fujimaki and Nakayama [91] reported the treatment of 11 patients with early oesophageal cancer using PDT. Nine patients remained in remission by the end of the study (median follow-up 13-48 months). However, 1 patient developed a recurrence 18 months later. One broncho-oesophageal fistula and one oesophageal stenosis occurred.

McCaughan et al. [93] conducted a prospective study (between 1982 and 1994) in which 77 patients with oesophageal cancer (not suitable for more radical therapy) were treated with PDT. Follow-up was 100\%. They used argon dye laser therapy, initial treatment was with a haematoporphyrin derivative as the photosensitiser and latterly dye haematoporphyrin ether, injected intravenously 1-3 days before treatment. They found that for those in clinical stage 1 , the estimated 5 -year survival was $62 \%$. This is comparable with other reports of 5-year survival after surgery (ranging between 46 and 70\%) [94-99]. Four patients developed fistulas, but all had advanced squamous cell carcinoma and had received different therapies prior to PDT. Four patients developed strictures, manageable by bouginage. This study looked at patients who were otherwise unfit for any other form of treatment such as radical surgery, chemotherapy etc., and, therefore, they were at high risk of complications. The use of a first-generation photosensitiser was the only agent available and, therefore, photosensitivity of the skin was inevitable. However, despite the number of reported complications it is fair to point out that other treatment regimes are associated with their share of post-treatment complications $[100,101]$.

Monnier et al. [92] treated 15 patients with superficial oesophageal cancer by a mixture of bouginage and photodynamic therapy and reported an initial remission rate of $80 \%$, three recurrences developed within 3 months of treatment. The remaining 12 patients remained in remission (follow-up range 6-60 months). Two oesophageal perforations and one stenosis were reported in this study.

Spinelli et al. [102] reported the treatment of 20 patients with superficial oesophageal cancer by PDT. $79 \%$ showed a response. The overall result showed a remission rate of $73 \%$ and the treatment was particularly good (remission rate of $86 \%$ ) in tumours which were $<1 \mathrm{~cm}$ in diameter.

Sibille et al. [103] reported the treatment of 123 patients with small oesophageal tumours $(0.5-4 \mathrm{~cm}$ in diameter) who were not fit for surgery. A remission rate of $87 \%$ at 6 months with an overall 5-year disease-specific survival rate of $74 \%$ was reported. This was a very encouraging report with results comparable or superior to other modalities of treatment. Others have reported similar experience (table 2) [74, 104-107].

In China and Japan where it appears that the rate of detection of early oesophageal and gastric cancer is higher than that in the West, photodynamic therapy has been used in the treatment of early cancer [90, 108, 109]. The numbers of patients involved in these studies are small and the follow-up period is limited (maximum of 19-41 months).

Kato et al. [109] reported the treatment of 66 patients with oesophageal cancer, remission was achieved in $80 \%$ with no recurrence (during the follow-up period of up to 36 months). The patients with early oesophageal cancer had an encouraging tumour-free follow-up [110]. 
Table 2. Summary of reported cases of oesophageal cancer treated by PDT

\begin{tabular}{|c|c|c|c|c|}
\hline Reference & $\begin{array}{l}\text { Number of } \\
\text { patients }\end{array}$ & Stage of tumour & $\begin{array}{l}\text { Complete response/ } \\
\text { remission rate }\end{array}$ & Duration of follow-up, months \\
\hline \multicolumn{5}{|l|}{ Early cancers } \\
\hline Fujimaki and Nakayama [91] & 11 & Early & $82 \%$ & $13-48$ \\
\hline Patrice et al. [88] & 8 & Early & $50 \%$ & 10.8 \\
\hline Calzavara et al. [89] & 20 & Superficial & $40 \%$ & $5-20$ \\
\hline Monnier et al. [92] & 15 & Superficial & $80 \%$ & $6-60$ \\
\hline Sibille et al. [103] & 123 & Small & $74 \%$ & 5 years \\
\hline Kato et al. [109] & 66 & Early & $80 \%$ & 36 \\
\hline Overholt et al. [87] & 14 & Superficial & $100 \%$ & $6-22$ \\
\hline Tian et al. [105] & 13 & Superficial & $92 \%$ & $21-32$ \\
\hline Gossner et al. [107] & 22 & Early & $77 \%$ & $1-30$ \\
\hline McCaughan et al. [93] & 8 & Stage I & $87 \%$ & $62 \% 5$-year survival \\
\hline Hayata et al. [49] & 6 & Early & $66 \%$ & $19-41$ \\
\hline Spinelli et al. [102] & 20 & Superficial & $73 \%$ & 5 years \\
\hline \multicolumn{5}{|l|}{ Advanced cancer } \\
\hline McCaughan et al. & 11 & Stage II & $100 \%$ (initial/1 month) & Median survival 12 months \\
\hline \multirow[t]{2}{*}[93,111,112]{} & 26 & Stage III & 100\% (initial/1 month) & Median survival 6.2 months \\
\hline & 32 & Stage IV & 97\% (initial/1 month) & Median survival 3.5 months \\
\hline Thomas et al. [104] & 15 & Advanced & $100 \%$ (initial) & 24 \\
\hline Heier et al. [115] & 32 & Advanced & $91 \%$ (initial) & Median relief of symptoms ( 84 days) \\
\hline Jin et al. [110] & 207 & advanced/recurrent & $16.40 \%$ & 8 years \\
\hline
\end{tabular}

\section{Advanced Cancer}

McCaughan et al. [111, 112] treated 56 patients with inoperable oesophageal cancer. In all patients tumour diminution occurred and swallowing improved (an increase in the patent diameter of the oesophagus from 6 to $9 \mathrm{~mm}$ ). Using 5ALA and low-dose PDT, Regula et al. [106] reported the treatment of 18 patients with colorectal, duodenal and oesophageal tumours. This resulted in superficial mucosal necrosis with fibrinous exudation. The group was disappointed with the fact that the depth of necrosis was very limited using 5ALA; however, this was a pilot study using a relatively low dose of PDT in a small number of patients. They suggested that the use of 5ALA in PDT might be more appropriate in the treatment of relatively superficial abnormalities such as Barrett's oesophagus than for the treatment of cancer.

Jin et al. [110] reported the treatment of 207 patients with advanced gastrointestinal tumours (121 inoperable and 86 recurrent) with PDT (using HPD). Remission was achieved in $16.4 \%$ of advanced cancers of the oesophagus, cardia and body of the stomach. They suggested that when cancer is $<50 \mathrm{~mm}$ in diameter, PDT could be curative.

The palliative treatment of dysphagia caused by malignant strictures, using stents [113] or laser therapy [114], is now very successful, easy to perform and has a low complication rate. Few researchers compared these modalities with PDT. Heier et al. [115] compared the use of PDT with Nd-YAG laser in the management of obstructing oesophageal cancer. In a randomised trial involving 52 patients (32 received PDT, 20 received Nd-YAG), both modalities relieved dysphagia but PDT resulted in a longer duration of response $(\mathrm{p}<0.008)$.

Furthermore PDT may have a role to play in the treatment of tumour ingrowth in expandable oesophageal stents. Eight such patients were treated for this problem by Scheider et al. [116] with success.

\section{PDT in Gastric Cancer}

The use of PDT in treating gastric cancer is technically more complicated owing to gastric folds, peristalsis and the shape of the stomach itself which may allow limited access to specific areas of abnormality. Earlier reports of the use of PDT in the treatment of gastric cancer were disappointing $[48,90,109,117,118]$, suggesting that PDT is only useful in the treatment of superficial cancer. The most encouraging result in recent years is that reported by Kato et al. [109]. They treated 133 cases of 
gastric cancer (120 of which were early tumours) and initial remission was achieved in $100 \%$ of patients, but recurrences occurred in $22.2 \%$ of treated patients (followup was up to 3 years).

Kasugai [119] reported the treatment of 81 gastric cancer patients with PDT showing a remission rate ranging from 85 to $98 \%$ in patients who were followed up for a period of 3-5 years.

Spinelli et al. [102] reported treatment with PDT of patients with early gastric cancer $(n=13)$. The response rate was $71 \%$, and in those who responded the remission rate was $85 \%$ (follow-up period of 3-58 months).

\section{PDT in Colorectal Cancer}

Photodynamic therapy has been in use in colorectal cancer for the last 10 years. However, the number of reports of patients treated by this modality is small. Dohmoto et al. [120] reviewed the reported cases and found that, in 71 patients with rectal cancer treated by PDT, $35 \%$ had a complete response, $44 \%$ had a partial response and $21 \%$ had no response.

In the absence of large prospective or even retrospective reports or randomised controlled trials comparing this modality with other palliative treatments or radical treatment of rectal cancer, no conclusion can be drawn about the efficacy of PDT in the management of rectal tumours. However, these early reports are very encouraging.

\section{Conclusions}

PDT is a promising technique for producing local in situ ablation of small areas of premalignant and malignant lesions in the gastrointestinal tract, with accuracy and safe healing.

PDT is best indicated for local treatment of mucosal and submucosal cancer that cannot be treated by operation. In Japan where the percentage of early (often mucosal) gastric cancer detected exceeds 50\%, PDT is becoming a useful alternative or addition to endoscopic mucosal resection as a form of eradication therapy of these early tumours.

PDT allows exposure of a large area of mucosa and therefore may decrease the number of treatments required compared to laser.

Up till recently the clinical and experimental experience with PDT (using established photosensitisers) dem- onstrated that tissue penetration and the necrotic effect of PDT is probably limited to $5-10 \mathrm{~mm}$, making it less suitable for bulky tumours and more suitable for early tumours or high-grade dysplasia. However, more recently, new photosensitisers, such as MTHPC, have been shown to result in a deeper necrotic effect after interacting with light. In the treatment of prostatic cancer, unpublished reports suggest that tumours of $<3 \mathrm{~cm}$ in size could be destroyed using interstitial PDT. Pilot trials are now in progress in Germany examining the efficacy of intralesional injection of the photosensitiser (with or without) and the addition of a pro-drug. If, as it is hoped, a preferential enhancement of photosensitiser uptake by malignant tissue leading to greater tumour destruction while sparing normal tissue is reported, then the way will be open for greater use of PDT in treating larger gastrointestinal lesions in patients deemed unfit for radical surgery.

The role of PDT as a primary method of palliating malignant oesophageal strictures is less certain. This is because other methods of palliating dysphagia (such as stents and laser) are extremely successful and have fewer complications. However, PDT may be useful in treating tumour ingrowth over oesophageal stents without undermining the stent in situ.

PDT holds the promise of an eradication form of treatment for early cancer especially for patients deemed unfit for other treatment. Furthermore, PDT might prove a useful supplement to other techniques in order to eliminate small residual areas of tumour left after the main bulk has been removed by other methods.

The ideal photosensitiser, light source, and the longterm effects (including side effects) of PDT are still not clearly identified. But, PDT will undoubtedly play a significant role in endoscopic gastroenterology in the years to come. 


\section{References}

1 Meyer-Betz F: Untersuchungen über die biologische (photodynamische) Wirkung des Hämatoporphyrins und anderer Derivative des Blutund Gallenfarbstoffs. Dtsch Arch Klin Med 1913; 112:476-503

2 Lipson RL, Blades EJ, Gray MJ: Hematoporphyrin derivative for the detection and management of cancer. Cancer 1967;20:22552257.

3 Raab GH, Schneilder AF, Eirmann W, et al: Response of human endometrium and ovarian carcinoma cell-lines to photodynamic therapy. Arch Gynecol Obstet 1990;248:13-20.

4 Byrne CJ, Marshallsay LV, Ward AD: The composition of photophyrin. J Photochem Photobiol B 1990;6:13-27.

5 Sindelar WF, DeLaney TF, Tochner Z, et al: Technique of photodynamic therapy for disseminated intraperitoneal malignant neoplasms. Arch Surg 1991;126:318-324.

6 Fromm D, Kessel D, Webber J: Feasibility of photodynamic therapy using endogenous photosensitization for colon cancer. Arch Surg 1996;131:667-669.

7 Bedwell J, MacRobert AJ, Phillips D, Bown SG: Fluorescence distribution and photodynamic effect of ALA-induced PP IX in DMH rat colonic tumour model. Br J Cancer 1992; 65:818-824.

8 Loh CS, MacRobert AJ, Buonaccorsi G, Krasner N, Bown SG: Mucosal ablation using photodynamic therapy for the treatment of dysplasia: An experimental study in the normal rat stomach. Gut 1996;38:71-78.

9 Razum N, Balchum OJ, Profio AE, Carstens F: Skin photosensitivity: Duration and intensity following intravenous hematoporphyrin derivatives, $\mathrm{HpD}$ and DHE. Photochem Photobiol 1987;46:925-928.

10 Wooten RS, Ahlquist DA, Anderson RE, et al: Localisation of haematoporphyrin derivative to human colorectal cancer. Cancer 1989;64: 1569-1576.

11 Margaron P, Madarnas P, Quellet R, Van Lier $\mathrm{J}$ : Biological activities of phthalocyanines. XVII: Histopathologic evidence for different mechanisms of EMT-6 tumour necrosis induced by photodynamic therapy with disulfonated aluminum phthalocyanine or photofrin. Anticancer Res 1996;16:613-620.

12 Barr H, Tralau CJ, MacRobert AJ, Krasner N, et al: PDT in the normal rat colon with phthalocynine sensitization. Br J Cancer 1987;56: 111-118.

13 Nelson JS, Liaw LH, Orenstein A, Roberts WG, Berns MW: Mechanism of tumour destruction following photodynamic therapy with hematoporphyrin derivative, chlorin and phthalocyanine. J Natl Cancer Inst 1988;80: 1599-1605.

14 Reddi E, Lo Castro G, Biolo R, Jori G: Pharmacokinetic studies with zinc (II)-phthalocyanines in tumour bearing mice. Br J Cancer 1987; 56:597-600.
15 Reddi E, Zhou C, Menegaldo E, Jori G: Liposome- or LDL-administered zinc (II)-phthalocyanine as a photodynamic agent for tumours. I. Pharmacokinetic properties and phototherapeutic efficiency. Br J Cancer 1990;61:407411

16 Valduga G, Nonell S, Reddi E, Jori G, Braslavsky SE: The production of singlet molecular oxygen by zinc (II) phthalocyanine in ethanol and in unilamellar vesicles. Chemical quenching and phosphorescence studies. Photochem Photobiol 1988;48:1-5.

17 Zhou C, Shunji C, Jinsheng D, Junlin L, Jori G, Milanesi C: Apoptosis of mouse MS-2 fibrosarcoma cells induced by photodynamic therapy with Zn (II)-phthalocyanine. J Photochem Photobiol B 1996;33:219-223.

18 Ramington C: Prophyrin and haem biosynthesis and its control. Acta Med Scand 1966; 179(suppl 445):11-24.

19 Sima AAF, Kennedy JC, Balkeslee D, Robertson DM: Experimental porphyric neuropathy: A preliminary report. Can J Neurol Sci 1981;9: 105-114.

20 Loh CS, Bedwell J, MacRobert AJ, et al: Photodynamic therapy of the normal rat stomach: A comparative study between di-sulphonated aluminium phthalocyanine and 5-aminolaevulinic acid. Br J Cancer 1992;66:452-462.

21 Mlkvy P, Messmann H, Regula J, Conio M, Pauer M, Millson CE, MacRobert AJ, Bown SG: Sensitization and photodynamic therapy (PDT) of gastrointestinal tumors with 5-aminolaevulinic acid (ALA) induced protoporphyrin IX (PP IX). A pilot study. Neoplasma 1995; 42:109-113.

22 Levy JG, Waterfield E, Richter A, et al: Photodynamic therapy of malignancies with benzoporphyrin derivative monoacid ring A. Proc Soc Photo-Optical Instr Eng 1994;2078:91101

23 Potter WR: The theory of photodynamic dosimetry: Consequences of photodestruction of sensitizer. Proc SPIE. Lasers Med 1986;712: 124-129.

24 Ris $\mathrm{HB}$, Altermat $\mathrm{JH}$, Inderbitzi R, Hess R, Nachbur B, Stewart JCM, Wang Q, Lim CK, Bonnett R, Berenbaum MC, Althaus U: Photodynamic therapy with chlorins for diffuse malignant mesothelioma: Initial results. Br J Cancer 1991;64:1116-1120.

25 Roberts WG, Smith KM, McCullough JL, Berns MW: Skin photosensitivity and photodestruction of several potential photodynamic sensitizers. Photochem Photobiol 1989;49: 431-438.

26 Nelson JS, Roberts WG, Berns JW: In vivo studies in the utilisation of mono-L-aspartate chlorin (NPe6) for photodynamic therapy. Cancer Res 1987;47:4681-4685.

27 Messnann H, Baumler W, Debl K, et al: Indocyanine green: A new photosensitizer for PDT in human colon carcinoma cells? Intracellular uptake and phototoxic effects. Gastroenterology 1997;112:A614.
28 Messnann H, Baumler W, Debl K, et al: Phototherapy of colon, hepatoma and differently graded pancreatic carcinoma cell lines after sensitization with Indocyanine green. Gastroenterology 1997;112:A614.

29 Weishaupt KR, Gomer CJ, Dougherty TJ: Identification of singlet oxygen as the cytotoxic agent in photoactivation of a murine tumour. Cancer Res 1976;36:2326-2329.

30 Foote CS: Mechanisms of photosensitized oxidation. Science 1968;162:963-967.

31 Robinson RS, Roberts AJ, Campbell ID: Photo oxidation on b-hydrobutyrate dehydrogenase: Studies on membrane fragments and intact mitochondria. Photochem Photobiol 1987;45: 231-234.

32 Varnes ME, Bayne MT, Bright GR: Reduction in intracellular $\mathrm{pH}$ is not the mechanism for the synergistic interaction between photodynamic therapy and Nogericin. Photochem Photobiol 1996;64:853-858.

33 Dougherty TJ, Lawrence G, Kaufman JH, et al: Photoradiation in the treatment of recurrent breast carcinoma. J Natl Cancer Inst 1979;62: 231-237.

34 Dougherty TJ, Kaufman JH, Goldfarb A, et al: Photoradiation therapy for the treatment of malignant tumours. Cancer Res 1978;38: 2628-2635.

35 Chopp M, Derski MO, Madigan L, et al: Sensitivity of 9L gliosarcomas to photodynamic therapy. Radiat Res 1996;146:461-465.

36 Cairnduff F, Stringer MR, Hudson EJ, et al: Superficial photodynamic therapy with topical 5ALA for superficial primary and secondary skin cancer. Br J Cancer 1994;69:605-608.

37 Schmidt S, Wagner U, Oehr P, Krebs D: Clinical use of photodynamic therapy in gynecologic tumour (in German). Zentralbl Gynäkol 1992; 114:307-311.

38 Tromberg BJ, Svaasand LO, Fehr MK, et al: A mathematical model for light dosimetry in photodynamic destruction of human endometrium. Phys Med Biol 1996;41:223-237.

39 Balchum OJ, Doiron DR, Huth GC: HpD photodynamic therapy for obstructing lung cancer. Prog Clin Biol Res 1984;170:727-745.

40 Fan KF, Hopper C, Speight PM, et al: Photodynamic therapy using 5-ALA for premalignant and malignant lesions of the oral cavity. Cancer 1996;78:1374-1383.

41 Overholt BR, Panjehpour M: Photodynamic therapy for Barrett's oesophagus: Clinical update. Am J Gastroenterol 1996;91:9.

42 Wang KK, Gutta K, Laukka MA: A prospective randomised trial of low dose PDT in the treatment of Barrett's oesophagus. Gastroenterology 1994;106:A208.

43 Berenson MM, Johnson TD, Markowitz NR, et al: Restoration of squamous mucosa after ablation of Barrett's oesophageal epithelium. Gastroenterology 1993;104:1686-1691. 
44 Nyamekye I, Buonaccorsi G, McEwan J, et al: Inhibition of intimal hyperplasia in balloon injured arteries with adjunctive phthalocyanine sensitized photodynamic therapy. Eur $\mathbf{J}$ Vasc Endovasc Surg 1996;11:19-28.

45 Garza OT, Abati A, Sindelar WF, et al: Cytologic effects of photodynamic therapy in body fluids. Diagn Cytopathol 1996;14:356-361.

46 Chan WS, Brasseur N, La Madeleine C, Van Lier JE: Evidence for different mechanisms of EMT-6 tumour necrosis by photodynamic therapy with disulfonated aluminum phthalocyanine or photofrin: Tumour cell survival and blood flow. Anticancer Res 1996;16:18871892.

47 Fiedler DM, Eckl PM, Krammer B: Does 5aminolaevulinic acid induce genotoxic effects? J Photochem Photobiol B 1996;33:39-44.

48 Gibson SL, Murand RS, Chazen MD, et al: In vitro sensitization of tumour cell enzymes by photofrin II administered in vivo. Br J Cancer 1989;59:47-53.

49 Hayata Y, Kato H, Okitsu H, et al: Photodynamic therapy with hematoporphyrin derivative in cancer in the upper gastrointestinal tract. Semin Surg Oncol 1985;1:1-11.

50 Mitchell JB, McPhearson S, DeGraff W, et al: Oxygen dependence of hematoporphyrin derivative induced photoinactivation of Chinese hamster cells. Cancer Res 1985;45:2008-2011.

51 Moan J, Sommer S: Oxygen dependence of the photosensitizing effect of hematoporphyrin derivative in NHIK-3025 cells. Cancer Res 1985; 45:1608-1610

52 Henderson BW, Donovan JM: Release of prostaglandin E2 from cells by photodynamic treatment in vivo. Cancer Res 1989;49:6896-6900.

53 Fingar VH, Wieman TJ: Studies on the mechanism of photodynamic therapy induced tumour destruction. Proc SPIE Photodynamic Therapy: Mechanisms II 1990;1203:168-177.

54 Van Geel IPJV, Oppelaar H, Rijken PFJW, et al: Vascular perfusion and hypoxic areas in RIF-1 tumours after photodynamic therapy. $\mathrm{Br}$ J Cancer 1996; 73:288-293.

55 Chapman JD, McPhee MS, Walz N, et al: Nuclear magnetic resonance spectroscopy and sensitizer adduct measurements of photodynamic therapy induce ischaemia in solid tumors. J Natl Cancer Inst 1991;22:1650-1659.

56 Overholt BF, Panjehpour M, DeNova RC, Peterson MG, Jenkins C: Balloon photodynamic therapy of esophageal cancer: Effect of increasing balloon size. Lasers Surg Med 1996;18: 248-252.

57 Nseyo UO, Whalen RK, Duncan MR, Berman B, Lundahl SL: Urinary cytokines following photodynamic therapy for bladder cancer. A preliminary report. Urology 1990;36:167-171.

58 Jori G, Beltrami M, Reddi E, et al: Evidence for a major role of plasma lipoproteins as haematoporphyrin carriers in vivo. Cancer Lett 1984; 24:291-297.

59 Korblik M: Low density lipoprotein receptor pathway in the delivery of photofrin. How much is it relevant for selective accumulation of the photosensitizer in tumours? J Photochem Photobiol 1992;12:107-109.
60 Hamblin MR, Newman EL: On the mechanism of tumour localising effect in photodynamic therapy. J Photochem Photobiol B 1994; 23:3-8.

61 Korbelik M, Krosl G, Chaplin DJ: Photofrin uptake by murine macrophages. Cancer Res 1991;51:2251-2255.

62 Allison BA, Waterfield E, Richter AM, Levy JG: The effects of plasma lipoprotein on in vitro tumour cell killing and in vivo tumour photosensitization with benzoporphyrin derivative. Photochem Photobiol 1991;54:709-714.

63 Puolakkainen P, Schroder T: Photodynamic therapy of gastrointestinal tumours: A review. Dig Dis 1992;10:53-60.

64 Overholt BF, Panjehpour M, De Novo RC, Peterson MG: Photodynamic therapy for esophageal cancer using a $180^{\circ}$ windowed oesophageal balloon. Lasers Surg Med 1994;14: 27-33.

65 Overholt BF, Panjehpour M, Denovo R, Peterson $\mathrm{M}$ : A centering balloon for PDT for oesophageal cancer tested in a canine model. Gastrointest Endosc 1993;39:782-787.

66 Kirschner RA, Unger M, Imber P: An introduction to dye lasers and photoradiation therapy. Surg Clin North Am 1984;64:939-940.

67 Kashtan H, Haddad R, Yossiphov Y, Bar-On S, Skornick Y: Photodynamic therapy of colorectal cancer using a new light source: From in vitro studies to a patient treatment. Dis Colon Rectum 1996;39:379-383.

68 Dougherty TJ, Marcus SL: Photodynamic therapy. Eur J Cancer 1992;28A:1734-1742.

69 McCaughan JS, Hawley PC, Walker J: Management of endobronchial tumours: A comparative study. Semin Surg Oncol 1989;5:38-47.

70 Loh CS, MacRobert AJ, Bedwell J, et al: Oral versus intravenous administration of 5-aminolaevulinic acid for photodynamic therapy. $\mathrm{Br} \mathrm{J}$ Cancer 1993; 68:41-51.

71 Overholt BF, Panjehpour M: Barrett's oesophagus: PDT for ablation of dysplasia, reduction of specialised mucosa and treatment of superficial oesophageal cancer. Gastrointest Endosc 1995;42:64-70.

72 Laukka MA, Wang KK: Initial results using low-dose photodynamic therapy in the treatment of Barrett's oesophagus. Gastrointest Endosc 1995;42:59-63.

73 Gossner L, Hahn C: Oral administration of 5 aminolevulinic acid for photodynamic therapy in patients with gastrointestinal carcinomas: Preliminary results. Gastroenterology 1994; 106:A387.

74 Overholt BF, Panjehpour M: Photodynamic therapy for Barrett's oesophagus: Clinical update. Am J Gastroenterol 1996;91:1719-1723.

75 Barr H, Shepherd NA, Dix A, Roberts DJH, Tan WC, Krasner N: Eradication of high-grade dysplasia in columnar-lined (Barrett's) oesophagus by photodynamic therapy with endogenously generated protoporphyrin IX. Lancet 1996;348:584-585.

76 Verspaget HW, Torremans PAJ, Van Lerssel AJHM, et al: Photodynamic therapy affects spontaneous and NK cell mediated tumour cell lysis. Gastroenterology 1997;112:A674.
77 Cohen S, Margalit R: Binding of porphyrin to human serum albumin. Structure-activity relationships. Biochem J 1990;270:325-330.

78 Amano T, Prout GR Jr, Lin CW: Intratumour injection as a more effective means of porphyrin administration for photodynamic therapy. J Urol 1988;139:392-395.

79 Veenhuizen RB, Marijnissen JPA, Kenemans $\mathrm{P}$, et al: Intraperitoneal PDT of rat CC531 adenocarcinoma. Br J Cancer 1996;73:13871392.

80 WongKeeSong LM, Wang KK, Nourbaksh A: Intra-lesional administration of photosensitiser in photodynamic therapy: A novel approach. Gastrointest Endosc 1997;45:75.

81 Rebeiz N, Rebeiz CC, Arkins S, et al: Photodestruction of tumor cells by induction of endogenous accumulation of protoporphyrin IX: Enhancement by 1,10-phenanthroline. Photochem Photobiol 1992;55:431-435.

82 Rebeiz N, Arkins S, Rebeiz C, et al: Induction of tumour necrosis by 5-ALA and 1,10-phenanthroline photodynamic therapy. Cancer Res 1996;56:339-344.

83 Kloek J, Akkermans W, Van Henegouwen GMJB: Derivative of 5-aminolaevulinic acid for photodynamic therapy: Enzymatic conversion into protoporphyrin. Photochem Photobiol 1998;67:150-154.

84 Watson A: A study of quality and duration of survival following resection, endoscopic intubation and surgical intubation in oesophageal carcinoma. Br J Surg 1985;69:585-588.

85 Fein R, Kelson D, Geller N, et al: Adenocarcinoma of the oesophagus and gastroesophageal junction: Prognostic factors and results of therapy. Cancer 1985;56:2512-2518.

86 Kelsen D: Treatment of advanced oesophageal cancer. Cancer 1982;50(suppl 2):2576-2581.

87 Overholt BF, Panjehpour M, Teffetellar E, Rose M: PDT for treatment of early adenocarcinoma in Barrett's oesophagus. Gastrointest Endosc 1993;39:73-76.

88 Patrice T, Foultier MT, Yactayo S, et al: Endoscopic PDT with haematoporphyrin derivative for primary treatment of gastrointestinal neoplasm in inoperable patients. Dig Dis Sci 1990; 35:545-552.

89 Calzavara F, Tomio L, Corti L, et al: Oesophageal cancer treated by PDT alone or followed by radiation therapy. J Photochem Photobiol B 1990;6:167-194.

90 Tajiri H, Daikuzono N, Joffe SN, Oguro Y: Photoradiation therapy in early gastro-intestinal cancer. Gastrointest Endosc 1987;33:8890.

91 Fujimaki M, Nakayama K: Endoscopic laser treatment of superficial oesophageal cancer. Semin Surg Oncol 1986;2:248-256.

92 Monnier P, Savary M, Fontolliet C, et al: Photodetection and photodynamic therapy of early squamous cell carcinomas of the pharyns, oesophagus and tracheobronchial tree. Lasers Med Sci 1990;5:149-168.

93 McCaughan J Jr, Ellison EC, Guy JT, et al: Photodynamic therapy for oesophageal malignancy: A prospective twelve-year study. Ann Thorac Surg 1991;62:1005-1010. 
94 Sugimachi K, Ikebe M, Kitamura K, et al: Long-term results of oesophagectomy for early oesophageal carcinoma. Hepatogastroenterology 1993;41:203-206.

95 Vigneswaran WT, Trastek VF, Pairolero PC, et al: Transhiatal oesophagectomy for carcinoma of the oesophagus. Ann Thorac Surg 1993;56:838-846.

96 Skinner DB, Ferguson MK, Soriano A, et al: Selection of operation for oesophageal cancer based on staging. Ann Surg 1986;204:391401.

97 Baba M, Aikou T, Yoshinaka H, et al: Longterm results of subtotal oesophagectomy with three field lymphadenectomy for carcinoma of the thoracic oesophagus. Ann Surg 1994; 219:310-316.

98 Gertsch P, Vauthey JN, Lustenberger AA, Friedlander-Klar H: Long-term results of transhiatal oesophagectomy for oesophageal carcinoma. Cancer 1993;72:2312-2319.

99 Moghissi K: Surgical resection of stage I cancer of the oesophagus and cardia. Br J Surg 1992;79:935-937.

100 Hishikawa Y, Kamikonya N, Tanaka S, Miura T: Oesophageal stricture following highdose-rate intracavitary irradiation for oesophageal cancer. Radiology 1986;159:715716.

101 Hishikawa Y, Tanaka S, Miura T: Oesophageal fistula associated with intracavitary irradiation for oesophageal carcinoma. Radiology 1986;159:549-551.

102 Spinelli P, Mancini A, Fante MD: Endoscopic treatment of gastrointestinal tumours: Indications and results of laser photocoagulation and photodynamic therapy. Semin Surg Oncol 1995; 11:307-318.
103 Sibille A, Lambert R, Souquet JC, Sabben G, Descos F: Long-term survival after photodynamic therapy for oesophageal cancer. Gastroenterology 1995;108:337-344.

104 Thomas RJ, Abbott M, Bhathal PS, et al: High dose photoirradiation of oesophageal cancer. Ann Surg 1987;206:193-199.

105 Tian ME, Qui SL, Ji Q: Preliminary results of haematoporphyrin derivative laser treatment for 13 cases of early oesophageal carcinoma. Adv Exp Med Biol 1985;193:21-25.

106 Regula J, MacRobert AJ, Gorchein A, Buonaccorsi GA, Thorpe SM, Spencer GM, Hatfield ARW, Bown SG: Photosensitisation and photodynamic therapy of oesophageal, duodenal and colorectal tumours using 5 aminolaevulinic acid induced protoporphyrin IX: A pilot study. Gut 1995;36:67-75.

107 Gossner L, Stolte M, Sroka R, et al: Photodynamic ablation of high grade dysplasia and early cancer in Barrett's oesophagus by means of 5ALA. Gastroenterology 1998;114:448455.

108 Wang KK, Geller A: PDT for early oesophageal cancer: Light versus surgical might. Gastroenterology 1995;108:593-607.

109 Kato H, Kito T, Furuse K: Photodynamic therapy in the early treatment of cancer (in Japanese). Gan To Kagaku Ryoho 1990;17: 1833-1838.

110 Jin M, Yang B, Zhang W, Wang Y: Photodynamic therapy for upper gastrointestinal tumours over the past 10 years. Semin Surg Oncol 1994;10:111-113.

111 McCaughan JS, Williams TE, Bethel BH: Palliation of oesophageal malignancy with photodynamic therapy. Ann Thorac Surg 1985; 40:113-119.

112 McCaughan JS, Nims A, Guy JT, et al: Photodynamic therapy for oesophageal tumours. Arch Surg 1989;124:74-80.
113 Cwikiel M, Cwikiel W, Albertson M: Palliation of dysphagia in patients with malignant oesophageal strictures. Acta Oncol 1996;35: 75-79.

114 Dallal HJ, Grieve D, Ghosh S, Penman I, Palmer KR: Expandable metallic stents versus Nd-YAG laser therapy for the palliative treatment of oesophageal cancer: A randomised trial. Gut 1998;42(suppl 1):TW265.

115 Heier SK, Rothman KA, Heier LM, Rosenthal WS: Photodynamic therapy for obstructing oesophageal cancer: Light dosimetry and randomised comparison with Nd-YAG laser therapy. Gastroenterology 1995;109:63-72.

116 Schneider DM, Cirocco M, Haber GB, et al: Photodynamic therapy for the treatment of tumour ingrowth in expandable oesophageal stents. Endoscopy 1997;29:271-274.

117 Song SZ, Li JH, Zou J: Haematoporphyrin derivative and laser photodynamical reaction in the diagnosis and treatment of malignant tumours. Lasers Surg Med 1985;5:61-66.

$118 \mathrm{Hu}$ C, Li JY, Jin ML, Yang BQ: Pathologic study on the treatment-effect of hematoporphyrin derivative in carcinoma of the gastric cardia (in Chinese). Chung Hua Chung Liu Tsa Chih 1988;10:197-199.

119 Kasugai T: Endoscopic treatment for gastric tumours: Long-term prognosis. Proc 48th Meet Japanese Research Society for Gastric Cancer, Nagoya, 1997.

120 Dohmoto M, Hunerbein M, Schlag PM: Palliative endoscopic therapy of rectal carcinoma. Eur J Cancer 1996;32A:25-29.

121 Panjehpour M, Overholt BF, Denovo R, Sneed R, Peterson M: Centering balloon to improve oesophageal PDT. Laser Surg Med 1992;12:631-638. 